\title{
Challenges and Strategies of College Students' Ideological and Political Education in the Internet Environment
}

\author{
$\mathrm{SHI} \mathrm{Li}$ \\ Wuhan Business University,Wuhan,430056 \\ ccnushili@163.com
}

Keywords: Challenges, Strategies, College Students, Ideological and Political Education, Internet Environment

\begin{abstract}
With the continuous development of modern information technology, the Internet is also at an unimaginable speed to enter our lives. Network shows the infinite charm of technology in the political, economic, scientific and cultural fields. This paper attempts to analyze the opportunities and challenges brought by the network environment, seek to face the challenges of the network environment, strengthen the ideological and political education of college students, so as to better strengthen and improve the ideological and political education for college students.
\end{abstract}

\section{Introduction}

With the continuous development of modern information technology, the Internet is also at an unimaginable speed to enter our lives. Network in the political, economic, scientific and cultural fields show the infinite charm of technology. The network is playing its infinite influence, quickly changed people's production methods, lifestyle and way of thinking, which led to a profound social change. With the development and popularization of campus network technology, the number of Internet students with college students as the main body is increasing. The computer network has become an important channel for college students to acquire knowledge and information. It also deeply affects the students' learning, life and even their ideas. However, from the history of human science and technology development, any science and technology development is a double-edged sword both on social development have a positive impact, but also inevitably bring many negative effects. The development of the network is no exception. Network not only to the ideological and political education in colleges and universities to provide a rare opportunity, but also brought a serious challenge. In the face of the turbulent development trend of the network, the party and the government put forward the requirements of formalizing and making good use of the Internet, seizing the network and trying to enhance the timeliness of ideological and political education of college students. Therefore, how to ensure that college students ideological and political education work in the network environment to seize the opportunity to meet the challenge is given us a new issue.

The development of the network brings new opportunities to the ideological and political education of college students. Network for the ideological and political education of college students to explore a new platform to promote the network of students to promote the ideological awareness of the network ideological and political education is conducive to comprehensively improve the ideological and moral quality of college students to improve the comprehensive ability of college students. At the same time, the development of the network makes the ideological and political education of college students face severe challenges. The impact of the network on the ideological network of college students on the interpersonal and psychological health of college students had a negative impact on the popularity and development of the network makes the traditional ideological and political education is facing a huge challenge to the ideological and political education workers in colleges and universities facing severe challenges.

Facing the opportunities and challenges, how to strengthen the ideological and political education of college students in the network environment is an important subject. The countermeasures of strengthening the ideological and political education of college students in the 
network environment are to innovate the ideological and political education mode of college students, reform the educational methods, break the traditional single teaching mode, realize the two-way communication, make use of high-tech means and enhance the effect of ideological and political education to create a good environment. We should strengthen the campus network construction, ideological and political system with Chinese characteristics, under the guidance of government norms, the government, schools, social co-management should strengthen the ideological and political workers in the team building, update ideas, innovative ideological and political education ideas, improve the educators themselves quality and build a contingent of ideological and political education for college students in order to adapt to the development needs of the network.

\section{The Development of the Network Brings the Severe Challenges to the Ideological and Political Education of College Students}

Network Gives Bad Impact on the Ideological Ideas of College Students. First of all, the network for the Western developed capitalist countries, cultural infiltration and ideological erosion provides favorable conditions. The network has two very important features, one is open and the other is resource sharing. We should see that the network information is a set of useful information and harmful information, real information and false information in one, is beyond control cannot filter, Western developed capitalist countries is the use of this uncontrollable and cannot filter, by virtue of its financial and technical advantages, the use of information monopoly position, control the information content of the network, the socialist countries launched a "peaceful evolution." Second, the network of information on the ideological and physical and mental health students have misleading and negative impact. In the past, college students contact with outside information mainly through books, newspapers, news media and other means. Information through layers of screening to show the public is conducive to leading students from the positive to form a correct world outlook, outlook on life, values. As mentioned earlier, the network set of useful information and harmful information, real information and false information in one, is unable to control cannot filter. These spammers are uninterrupted in the spread of college students, no doubt the ideological point of view of college students have a great misleading effect

Network Has A Negative Impact on College Students' Interpersonal and Mental Health. The virtuality of the network makes everyone be an "invisible man" in the way of communication in the network. In other words, in the network, the interaction between people is not face to face, real interaction, but through a "interpersonal" conversion of virtual contacts. People face every day is a computer, long past, is bound to affect and change people's way of communication, living habits, resulting in barriers between people. The main realization of the more and more indifferent between people, the relationship between more and more shaky, the ability to communicate between people decline, resulting in loneliness, depression, depressed, depressed will depression and so on. If college students rely too much on the network will cause personality depressed, selfish cold, in interpersonal relationship ability decline, they encounter difficulties in real life tend to seek network comfort, escape reality, from reality. Long-term, will seriously affect their learning and life.

The Popularization and Development of the Network Makes the Traditional Ideological and Political Education in Colleges and Universities Face Challenges. In the network environment, the network of interactive, virtual, open and so on, making the traditional ideological and political education in colleges and universities faces severe challenges. Comrade Jiang Zemin pointed out: "In the face of the new situation and new situation, ideological and political work must inherit and play on the basis of fine traditions, and must strive for innovation and improvement in terms of content, form, methods, means and mechanisms and to strengthen the pertinence, effectiveness, initiative to make efforts to become the future to strengthen and improve the ideological and political work of the focus." (1) in the network environment, we should pay attention to the traditional ideological and political education innovation and reform, and enhance its targeted With the times. 
The Network Makes Ideological and Political Education Workers in Colleges and Universities Face Severe Challenges. Ideological and political education in colleges and universities shoulders the ideological and political education of college students' important mission and its own quality directly affects the quality of college students' ideological and political education. In the past, the ideological and political education model, ideological and political education has been in a dominant position, is the main communicator of information. The dominance of this kind of information dissemination can promote the establishment of the prestige of the educators, so as to provide favorable conditions for the smooth development of ideological and political work. With the advent of the Internet age, educated people to obtain information, knowledge channels increased, which will make the ideological and political education in colleges and universities are facing severe challenges.

\section{The Countermeasures to Strengthen the Ideological and Political Education in Facing of the Network Environment}

Innovative Education Model and Reform Education Methods. The traditional ideological and political education means mainly to instill the main, teaching mode is relatively simple, in the new environment of the network, ideological and political education must innovate the education model. The network is an open system, it expresses the desire of people to communicate, resource sharing requirements, at the same time, it imperceptibly change and affect the modern people exchanges and communication. In the traditional ideological and political education, educators have a high prestige and information superiority in the education process often dominate therefore, the implementation of the knowledge of one-way indoctrination. However, in the network environment, the process of knowledge transmission and content are equal, even in some cases, the educators have much more information than educators. In this case, the authoritative authority of the educator will be affected and affected. "In fact, this non-central network of features is conducive to the exchange of equal communication and interaction, to enable educators to use more heuristic, interactive, discussion of the working methods, a more clear understanding of student thinking to take a targeted way to be guided by the traditional single exchange in the one-man play or even unyielding heart really do two-way interaction, oral heart more clothes.

Create A Good Public Opinion Environment and Take the Initiative to Occupy the Network Position. Ideological and political education in colleges and universities must take the initiative to occupy the new position of ideological and political education on the Internet, to seize the commanding point of ideological and political education. Comrade Jiang Zemin pointed out that "we should attach great importance to the public opinion propaganda of the Internet. The general policy is to actively develop, make full use of strengthen management, promote disadvantages, give advantages and take the initiative to enhance the influence and combat effectiveness of online propaganda. And the new position of national ideological and political work, as our new channels of external publicity. "(2) to strengthen the construction of the campus network, the construction of red theoretical topics, clearly publicized Marxism-Leninism, Mao Zedong Thought and socialism with Chinese characteristics, the party line, the policy, policy education set up news practical columns, timely updates at home and abroad occurred in major hot news, and set up online forums to encourage students to freely express their views on hot issues and views to carry out online interactive health education, legal garden and a series of columns to strengthen the education of socialist legal system, education of socialist concept of honor and disgrace, to promote patriotism, collectivism carry forward the outstanding democratic culture, enhance the realization of the great rejuvenation of the Chinese nation's sense of responsibility and mission, the campus network into ideological and political education propaganda position.

Perfect the Network System Mechanism of College Students' Ideological and Political Education. Under the network environment, the ideological and political education of innovative college students must adhere to the guiding ideology of Marxism-Leninism, Mao Zedong Thought and socialism with Chinese characteristics as the guiding ideology. Theoretical education is the 
main way and channel of ideological and political education of college students. At present, the important task of theoretical education is to study Marxism-Leninism, Mao Zedong Thought and socialism system with Chinese characteristics. "Opinions" stressed that "in accordance with the full realization of the latest achievements of contemporary Marxist requirements and comprehensively strengthen the ideological and political theory of discipline construction, curriculum construction, teaching materials and teaching team building." Theory and practice should be combined teaching, continuous improvement working methods and innovative education model.

Strengthen the Ideological and Political Workers in the Team Building. In the current network environment, we should strengthen the ideological and political work of the team, cultivate a group of both a solid business knowledge base, a good ideological and moral theory of cultivation, but also familiar with network operation technology, good use of online media-assisted teaching new ideological and political education in colleges and universities, so as to adapt to the development requirements of the Internet age. Comrade Jiang Zemin pointed out that "the construction of a strong political work, fine work style, propaganda and ideological work team is to do propaganda and ideological work organization guarantee.

Ideological and political education should start from the current situation of the current network, starting from the actual needs of students to break the traditional face to face one-way inculcation of education, to be good at using the majority of students love the network information technology, the use of sound, the text in one of the multimedia, online interaction, increase the teaching of fun and vivid, and enhance the appeal of teaching and appeal, so as to achieve the purpose of teaching, improve teaching effectiveness. This requires the ideological and political education in colleges and universities should strengthen their own theoretical literacy and proficiency in ideological and political education theory at the same time, master the computer network technology, with the use of network information technology to carry out ideological and political education.

\section{Conclusion}

The mature and popularization of mobile Internet technology has brought new opportunities and challenges to the ideological and political education in colleges and universities at the same time, while changing people's way of life and way of thinking. The subject of ideological and political education is a very practical subject. Under the new situation, through the investigation and study of the new field of mobile Internet, the author has carried on the truthful, objective and comprehensive description and analysis to the ideological and political Education has important practical and theoretical significance.

\section{References}

[1] Huifang Zhou: Journal of Ideological \& Theoretical Education, Vol. 6 (2004) No 53, p.25-26

[2] Hongli Zhang: Red Flag Manuscript, Vol. 12 (2005) No 27, p.74-76

[3] Qin Guo: Computer and Network, Vol. 1 (2006) No 33, p.11-14

[4] Jieming Liu: E - Commerce, Vol. 3 (2007) No33, p.121-124

[5] Jia Xinzhang, Li Jingyuan. International Forum, Vol. 6 (2014) No 53, p.25-26 